\title{
Estimation of Power Transformer Loading Based on Population Growth: A Case Study in Kulon Progo Regency
}

\author{
Yudhi Ardiyanto ${ }^{*}$, Slamet Suripto ${ }^{1}$, Faaris Mujaahid ${ }^{1}$, Rohman Try Anshori ${ }^{1}$, Yessi Jusman ${ }^{1}$, \\ Fardhan Arkan ${ }^{2}$ \\ ${ }^{1}$ Department of Electrical Engineering, Universitas Muhammadiyah Yogyakarta \\ Jl. Lingkar Selatan, Tamantirto, Kasihan, Yogyakarta, Indonesia \\ ${ }^{2}$ Department of Electrical Engineering, Universitas Bangka Belitung \\ Kampus Terpadu Balun Ijuk Merawang Kabupaten Bangka, Bangka Belitung, Indonesia \\ *Corresponding author, e-mail: yudhi.ardiyanto@umy.ac.id
}

\begin{abstract}
Along with technological advances, it is estimated that the gross regional domestic product (GRDP) of Kulon Progo Regency increases annually by 7.6\%, and the population growth of Kulon Progo regency increases annually by 0.9\%. However, after assuming with Muara Bungo Regency as a reference to GRDP growth and Population of Kulon Progo Regency due to the influence of the Establishment of New Yogyakarta International Airport (NYIA) in 2019, the population growth every year is $15.78 \%$. While GRDP in 2018 until 2019 equals to $82.91 \%$ and next year equals to $7.6 \%$. Load forecasting the burden for the next ten years by using multiple linear regression affected by NYIA in 2019, the loading of the $150 \mathrm{kV}$ Wates substation is only up to 2021 for the power transformer I of $24.83 \mathrm{MW}$ and the power transformer II 55.40 MW. So it is estimated that for 2022, power transformer I and power transformer II of $150 \mathrm{kV}$ Wates Substation are no longer able to serve the loading. Then, in 2021 a feeder shift and uprating power transformer I need to be conducted. In 2024 a power transformer III is needed. In that year the feed formation from power transformer I and power transformer II was changed to power transformer III.
\end{abstract}

Keywords: Substation, Power Transformer, Multiple Linear Regression, Loading

\section{Introduction}

A power transformer is a static electrical device that is used to move power from one circuit to another by changing the voltage without changing the frequency [1]. In its purest form, the transformer consists of two coils and one mutual inductance. Primary coils are those that receive power, and secondary coils are connected to the load. The two coils are wrapped around a core consisting of laminated magnetic material [2]. The physical foundation of the transformer is mutual inductance between the two circuits connected by a shared magnetic flux that passes through the path of low reluctance. Both coils have high mutual inductance. If the primary coil is connected to a voltage, the current will flow back and forth on the loop.
Because the coil has a core, the current causes a magnetic flux that also changes at its core. Due to the changing magnets in the primary coil, emf induction will arise [3]-[4].

Power Transformer is a transformer that is commonly used in substations, both the Power substation and Distribution substation, where the transformer has a large power capacity. In the substation generator, the transformer is used to increase the voltage to the transmission voltage (higher voltage), which is 150 or $500 \mathrm{kV}$. Whereas in the Distribution substation, the transformer is used to reduce the transmission voltage to the primary or medium voltage, which is 11.6 or $20 \mathrm{kV}$ [5].

In this day and age electricity is one of the most important basic needs in the lives of the general public in various regions of Indonesia so that it is 
often used as a factor in the progress of the community along with technological developments. From BPS Yogyakarta data shows that the population growth of the Kulon Progo Regency continues to increase every year. In 2016, as many as 15,698 people became 16,239 people in 2017 , an increase of $3.44 \%$. The rapid population growth accompanied by high economic growth has caused the need for electricity to increase, so that adequate supply and distribution of electricity is needed, both in terms of technical and economic.

Rahman (2015) conducted a study on the forecast and analysis of the electricity needs of West Sumatra Province until 2024. The author conducted a study on the distribution transformer capacity for the Province of West Sumatra. Based on the results of research using multiple linear methods by predicting the next 10 years. For the household sector, the electricity demand is the highest in 2024, which is $2,332,704.91 \mathrm{MWh}$ with an average annual increase of 5.68 percent. However, if viewed from the highest average percentage increase per year, it is in the commercial sector at 7.08 percent. In the public sector the average percentage increase per year is 1.15 percent. The opposite happened in the industrial sector which declined by a percentage of 4.94 percent. This is due to the rapid advancement of industrial technology causing industrial companies to innovate to get energy sources and equipment sources that are more energy efficient [6].

Nugroho (2016) conducted a study of the evaluation of the ability of the $150 \mathrm{KV}$ old Ciligon substation transformer. The author forecasts 2 transformer units in the old Cilegon Substation 150 $\mathrm{kV}$. Based on calculations using the multiple linear regression method, the authors predict in the next 15 years the first transformer with a capacity of 56 (Megavolt-amperes) MVA. With the results that in 2030 the conditions of the first transformer are no longer able to serve a high load of 59.24 MVA $(106 \%)$. While the availability of installed transformer capacity is 56 MVA. Then the prediction of the second unit transformer with a capacity of 60 MVA in 2030 is still within the limit of the optimal standard of transformer operation that is equal to 47,025 MVA $(78 \%)$. So that the transformer can work optimally within the next 15 years [7].

Krisno (2017) conducted a study on the evaluation of the ability of power transformers based on population development and peak load at $150 \mathrm{KV}$ substation Cikupa. The author estimates the 2 transformer units in the $150 \mathrm{KV}$ Cikupa substation using the multiple linear regression method, the authors predict in the next 10 years the first transformer with a capacity of 60 MVA. With the results that in 2026 conditions in the first transformer are no longer able to serve a high load of 124 MVA (207\%). While in the second transformer with a capacity of 60MVA not able to serve the burden for the next 10 years in 2026 where the burden is predicted to reach 158.5 MVA (264\%). So that the transformer at the Cikupa Substation $150 \mathrm{KV}$ is overloaded with a load in the next 10 years [8].

In the $150 \mathrm{KV}$ Wates substation, it is necessary to estimate the load that will be installed in the future. This relates to the construction of NYIA (New Yogyakarta International Airport) in Kulon Progo Regency. Like the case in Muara Bungo District, with the construction of the airport in 2014, the GRDP increased significantly. From this increase the higher the welfare of the community that affects lifestyle as well as in the use of electrical energy. Thus the Kulon Progo Regency must be made an estimated transformer loading and if no estimated loading is made the $150 \mathrm{KV}$ Wates substation will experience an overload on the transformer used in channeling the load along with the development of the Kulon Progo Regency.

\section{Methods}

The equipment used in this study is a unit of Acer Intel (R) Core i5 notebooks, printers, cameras and reference books. This research was carried out at the $150 \mathrm{KV}$ Wates substation for 2 weeks from 12 to 23 March 2018.

1. Flowchart of Research

Flowchart for the research is presented in Fig. 1.

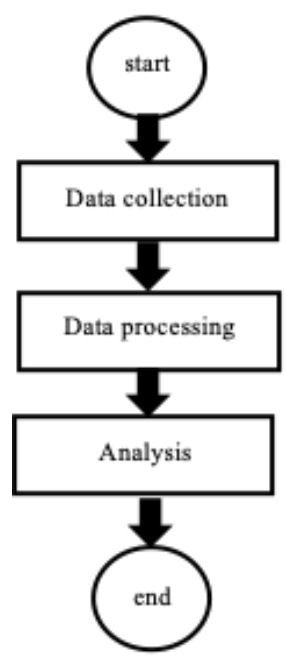

Fig. 1. Research flow chart

Journal of Electrical Technology UMY, Vol. 3, No. 4 
Based on the flow chart above, the research carried out includes the following steps:

1. Data Collection

The data for this study were taken directly at the $150 \mathrm{KV}$ Wates substation and the BPS of the Special Region of Yogyakarta. The data were taken from 2013 to 2016, the type of data taken was:

a. Monthly peak load data for 2013-2016 transformer I $30 \mathrm{MVA}$ and transformer II 60 MVA.

b. The rate of population growth and GRDP of Kulon Progo district in 2013-2016.

c. The rate of population growth and GRDP of Muara Bungo Regency 2010-2016.

\section{Data Analysis}

Electricity load growth in an area is always linear. Annual growth always increases with the influencing factors such as GRDP and population growth. With this background the researchers chose two methods, namely the method of multiple linear regression and the method of 3 assumptions from other districts with the same development.

The method of multiple linear regression can be seen from the following equation 1 .

$$
Y=a+b 1 X 1+b 2 X 2+\cdots+n
$$

Where,

$$
\begin{array}{ll}
\mathrm{Y} & =\text { dependent variable } \\
\mathrm{X} 1, \mathrm{X} 2 & =\text { independent variable } \\
\mathrm{a} & =\text { constant }(\text { value of } \mathrm{Y} \text { if } \mathrm{x} 1 \mathrm{x} 1 \ldots \mathrm{xn}=0) \\
\mathrm{b} 1, \mathrm{~b} 2 & =\text { regression coefficient }
\end{array}
$$

To get the values of $b 1, b 2$, and a, you can use the following equation:

$$
\begin{gathered}
\Sigma X_{1}^{2}=\Sigma X_{1}^{2}-\frac{\left(\Sigma X_{1}\right)^{2}}{n} \\
\Sigma X_{2}^{2}=\Sigma X_{2}^{2}-\frac{\left(\Sigma X_{2}\right)^{2}}{n} \\
\Sigma Y^{2}=\Sigma Y^{2}-\frac{(\Sigma Y)^{2}}{n} \\
\Sigma X_{1} Y=\Sigma X_{1} Y-\frac{\Sigma X_{1} \cdot \Sigma Y}{n} \\
\Sigma X_{2} Y=\Sigma X_{2} Y-\frac{\Sigma X_{2} \cdot \Sigma Y}{n} \\
\Sigma X_{1} X_{2}=\Sigma X_{1} X_{2}-\frac{\Sigma X_{1} \cdot \Sigma X_{2}}{n}
\end{gathered}
$$

So, from the above equation to find the values of b1 and b2 and a can be found using the following formula:

$$
b 1=\frac{\left[\left(\Sigma X 2^{2} \times \Sigma X 1 Y\right)-(\Sigma X 2 Y \times \Sigma X 1 X 2)\right.}{\left[\left(\Sigma X 1^{2} \times \Sigma X 2^{2}\right)-(\Sigma X 1 X 2)^{2}\right]}
$$

Then to find the value of b2 you can use the following formula:

$$
\begin{gathered}
b 2=\frac{\left[\left(\Sigma X 1^{2} \times \Sigma X 2 Y\right)-(\Sigma X 1 Y \times \Sigma X 1 X 2)\right.}{\left[\left(\Sigma X 1^{2} \times \Sigma X 2^{2}\right)-(\Sigma X 1 X 2)^{2}\right]} \\
a=\frac{(\Sigma Y)-(b 1 \times \Sigma X 1)-(\mathrm{b} 2 \times \Sigma X 2)}{n}
\end{gathered}
$$

Then population growth and GRDP use the following equation:

GRDP year $\mathrm{n}=($ GRDP year before $\mathrm{n} \times$ growth rate\%) + GRDP year before $n$

So to find growth (\%) use the following equation:

$$
P_{t}=P_{0}\left(1+\frac{X}{100}\right)^{t}
$$

Where,

$\mathrm{P}_{\mathrm{t}}=$ value in that year

$\mathrm{P}_{0}=$ value in the previous year $(\mathrm{pt})$

$\mathrm{X}=$ Value sought

$\mathrm{t}=$ time later to find the value of $\%$ loading can be done by dividing the results of the equation divided by the capacity of the transformer used.

\section{Results and Discussion}

\section{III.1. Population and GRDP Data of Kulon Progo Regency}

From this study, the estimated results of the 150 $\mathrm{KV}$ Wates substation transformer loading are as in Table I.

TABLE I

Total Population and GRDP of Kulon Progo

\begin{tabular}{ccc}
\hline \hline Year & $\begin{array}{c}\text { Total Population } \\
\text { (in thousandssoul) }\end{array}$ & $\begin{array}{c}\text { GRDP } \\
\text { (Million Rupiah) }\end{array}$ \\
\hline 2013 & 401 & 16,165 \\
2014 & 405 & 17,345 \\
2015 & 408 & 18,736 \\
2016 & 412 & 20,145 \\
\hline \hline
\end{tabular}

GRDP year $\mathrm{n}=($ GRDP year before $\mathrm{n} \times 7.6 \%)+$ GRDP year before $n$

1. GRDP $2017=(20,145 \times 7.6 \%)+20,145$ $=21,676$

2. GRDP $2018=(21,676 \times 7.6 \%)+21,676$ $=23,332$ 
A value of $7.6 \%$ is obtained from the GRDP of the Kulon Progo Regency while for population growth using the same equation but with a growth rate of $0.9 \%$ obtained from the results the same calculation to look for $7.6 \%$. From the calculation results obtained in the Table II.

After the above results are obtained, then make the following equation to find the transformer I constant value. Whereas to find transformer II equation using the same method as searching for transformer I equation with different peak load values. In order to obtain the transformer I equation as seen in Table III.

TABLE II

CAlCulation of Estimated Number of Population AND GRDP OF KULON PROGO REgENCY

\begin{tabular}{ccc}
\hline \hline Year & $\begin{array}{c}\text { Total Population } \\
\text { (in thousands soul) }\end{array}$ & $\begin{array}{c}\text { GRDP } \\
\text { (Million Rupiah) }\end{array}$ \\
\hline 2013 & 401 & 16,165 \\
2014 & 405 & 17,345 \\
2015 & 408 & 18,736 \\
2016 & 412 & 20,145 \\
2017 & 415.708 & 21,676 \\
2018 & 419.449 & 23,323 \\
2019 & 423.224 & 25,096 \\
2020 & 427.033 & 27,003 \\
2021 & 430.877 & 29,056 \\
2022 & 434.755 & 31,264 \\
2023 & 438.667 & 33,640 \\
2024 & 442.615 & 36,196 \\
2025 & 446.599 & 38,947 \\
2026 & 450.618 & 41,907 \\
2027 & 454.674 & 45,092 \\
\hline \hline
\end{tabular}

TABLE III

TRANSFORMER I REGRESSION EQUATION

\begin{tabular}{cccccc}
\hline \hline \multirow{2}{*}{ Transformer I } & \multirow{2}{*}{2013} & 2014 & 2015 & 2016 & $\sum$ \\
\hline Y (MW) & 14.9 & 15.1 & 17.7 & 18.6 & 66.3 \\
X1 & 401 & 405 & 408 & 412 & 1626 \\
X2 & 16.165 & 17.345 & 18.736 & 20.145 & 72.391 \\
X21 & 160801 & 164025 & 166464 & 169744 & 661034 \\
X22 & $261,307,225$ & $300,849,025$ & $351,037,696$ & $405,821,025$ & 1319,014971 \\
Y2 & 222.01 & 228.01 & 313.29 & 345.96 & 1109.27 \\
X1.X2 & $6,482,165$ & $7,024,725$ & $7,644,288$ & 8299,74 & $29,450,918$ \\
X1.Y & 5974.9 & 6115.5 & 7221.6 & 7663.2 & 26975.2 \\
X2.Y & $2,408,585$ & $2,619,095$ & $3,316,272$ & 374,697 & $1,209,092$ \\
\hline \hline
\end{tabular}

From the calculation of the regression equation above, we can find the values of a, b1, and b2 as follows:

$$
\begin{gathered}
\Sigma X_{1}^{2}=\Sigma X_{1}^{2}-\frac{\left(\Sigma X_{1}\right)^{2}}{n}=661034-\frac{1626^{2}}{4}=65 \\
\Sigma X_{2}^{2}=\Sigma X_{2}^{2}-\frac{\left(\Sigma X_{2}\right)^{2}}{n}=1319,015-\frac{72,391^{2}}{4}=8.9 \\
\Sigma Y^{2}=\Sigma Y^{2}-\frac{(\Sigma Y)^{2}}{n}=1109.27-\frac{66.3^{2}}{4}=10.35 \\
\Sigma X_{1} Y=\Sigma X_{1} Y-\frac{\Sigma X_{1} \cdot \Sigma Y}{n}=26975.2-\frac{1626 \cdot 66.3}{4}=24.25 \\
\Sigma X_{2} Y=\Sigma X_{2} Y-\frac{\Sigma X_{2} \cdot \Sigma Y}{n}=1209,092-\frac{72,391 \cdot 66.3}{4}=9 \\
\Sigma X_{1} X_{2}=\Sigma X_{1} X_{2}-\frac{\Sigma X_{1} \cdot \Sigma X_{2}}{n}=29450.92-\frac{1626 \cdot 72,391}{4}=24.38
\end{gathered}
$$

So to look for the burden of the next 10 years as follows:

$$
\begin{gathered}
b 1=\frac{\left[\left(\Sigma X 2^{2} \times \Sigma X 1 Y\right)-(\Sigma X 2 Y \times \Sigma X 1 X 2)\right]}{\left[\left(\Sigma X 1^{2} \times \Sigma X 2^{2}\right)-(\Sigma X 1 X 2)^{2}\right]} \\
=\frac{(8.9 \times 24.25)-(9 \times 24.38)}{(65 \times 8.9)-(24.38)^{2}} \\
=\frac{(215.828)-(219.42)}{(578.5-594.384)} \\
=\frac{-3.59}{-15.88} \\
=0.22
\end{gathered}
$$$$
b 2=\frac{\left[\left(\Sigma X 1^{2} \times \Sigma X 2 Y\right)-(\Sigma X 1 Y \times \Sigma X 1 X 2)\right]}{\left[\left(\Sigma X 1^{2} \times \Sigma X 2^{2}\right)-(\Sigma X 1 X 2)^{2}\right]}
$$ 


$$
\begin{gathered}
=\frac{(65 \times 9)-(24.25 \times 24.38)}{(65 \times 8.9)-(24.38)^{2}} \\
=\frac{(585-591.21)}{(578.5-594.384)} \\
=\frac{-6.21}{-15.88} \\
=0.39 \\
a=\frac{(\Sigma Y)-(b 1 \times \Sigma X 1)-(b 2 \times \Sigma X 2)]}{n} \\
=\frac{(66.3)-(0.22 \times 1626)-(0.39 \times 72.391)}{4} \\
=\frac{66.3-357.72-28.23}{4} \\
=\frac{-319.65}{4} \\
=-79.91 \\
Y=a+(b 1 \times \mathrm{X} 1)+(\mathrm{b} 2 \times X 2)+\cdots n
\end{gathered}
$$

As for the loading, the calculation of the equation can be seen below.

$$
\begin{aligned}
2017 & =-79.91+(0.22 \times 415.708+(0.39 \times 21.676) \\
& =20 \mathrm{MW} \\
2018 & =-79.91+(0.22 \times 419.449+(0.39 \times 23.323) \\
& =21 \mathrm{MW} \\
2019 & =-79.91+(0.22 \times 423.24+(0.39 \times 25.096) \\
& =22 \mathrm{MW}
\end{aligned}
$$

The equation is:

$$
\begin{aligned}
\% 2017 & =(20 \mathrm{MW} / 30 \mathrm{MW}) \times 100 \% \\
& =66.66 \%
\end{aligned}
$$

The results of the overall load calculation for the next 10 years can be seen in Table IV along with the percentage of loading for transformer I and transformer II without the influence of the airport.

From the data in Table IV, it can be seen that without the influence of NYIA transformer I for the next 10 years will only be able to serve up to 2023 with a load of $29.72 \mathrm{MW}$ in the heavy load category. Whereas for the years 2024 to 2027 the

\begin{tabular}{|c|c|c|c|c|}
\hline \multirow[b]{2}{*}{ Year } & \multicolumn{2}{|c|}{$\begin{array}{c}\text { Transformer I } \\
\text { 30 MVA }\end{array}$} & \multicolumn{2}{|c|}{$\begin{array}{c}\text { Transformer II } \\
60 \text { MVA }\end{array}$} \\
\hline & $\begin{array}{c}\text { No } \\
\text { NYIA } \\
\text { (MW) }\end{array}$ & $\begin{array}{l}\text { Percentage } \\
(\%)\end{array}$ & $\begin{array}{c}\text { No } \\
\text { NYIA } \\
\text { (MW) }\end{array}$ & $\begin{array}{l}\text { Percentage } \\
(\%)\end{array}$ \\
\hline 2013 & 14.92 & 49.73 & 7.94 & 13.23 \\
\hline 2014 & 14.40 & 48.00 & 10.45 & 17.42 \\
\hline 2015 & 17.70 & 59.00 & 14.00 & 23.33 \\
\hline 2016 & 18.60 & 62.00 & 13.46 & 22.43 \\
\hline 2017 & 20.00 & 66.66 & 16.52 & 27.54 \\
\hline 2018 & 21.46 & 71.55 & 18.66 & 31.10 \\
\hline 2019 & 22.99 & 76.62 & 20.86 & 34.76 \\
\hline 2020 & 24.57 & 81.90 & 23.12 & 38.54 \\
\hline 2021 & 26.21 & 87.38 & 25.46 & 42.44 \\
\hline 2022 & 27.93 & 93.10 & 27.88 & 46.47 \\
\hline 2023 & 29.72 & 99.05 & 30.38 & 50.64 \\
\hline 2024 & 31.58 & 105.27 & 32.97 & 54.95 \\
\hline 2025 & 33.53 & 111.77 & 35.65 & 59.42 \\
\hline 2026 & 35.57 & 118.57 & 38.43 & 64.06 \\
\hline 2027 & 37.70 & 125.68 & 41.32 & 68.87 \\
\hline
\end{tabular}
transformer I will be in a condition of overload load of $31.58 \mathrm{MW}$ for 2024 and $37.70 \mathrm{MW}$ in 2027 and for transformer II without the influence of NYIA for the next 10 years it is still able to serve loading with the highest load in 2027 of $41.32 \mathrm{MW}$ in the optimal load category with a $68.87 \%$ loading. Meanwhile, to see the difference in loading after the operation of NYIA in 2019 can be seen in Table V to find the burden estimated by the existence of the NYIA. Then to find the burden used Muara Bungo Regency as an assumption of the airport in Kulon Progo Regency as seen in Table V. From Table V it can be seen that the growth rate after the airport is shown in Fig. 2.

\section{TABLE IV}

COMPARISON TABLE OF LOAD TRANSFORMER I AND TRANSFORMER II WITHOUT THE EFFECT OF NYIA

TABLE V

Growth Rate Of MuARA Bungo ReGency 2010-2016

\begin{tabular}{ccc}
\hline \hline Year & $\begin{array}{c}\text { Total Population } \\
\text { (in thousands soul) }\end{array}$ & $\begin{array}{c}\text { GRDP } \\
\text { (in Million) }\end{array}$ \\
\hline 2010 & 303.135 & 4,033 \\
2011 & 310.737 & 4,755 \\
2012 & 320.300 & 5,446 \\
2013 & 329.934 & 6,198 \\
2014 & 336.320 & 11,808 \\
2015 & 344.100 & 12,985 \\
2016 & 351.878 & 14,351 \\
\hline \hline
\end{tabular}

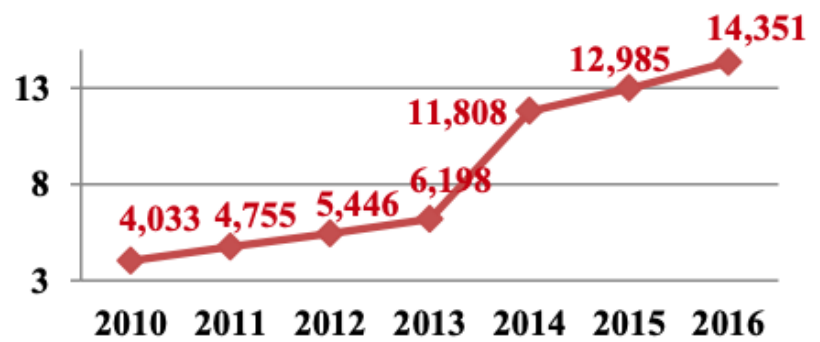

Fig. 2. GRDP growth rate of Muara Bungo Airport 20102016 
From BPS data on population and GRDP of Muara Bungo Regency in 2011 - 2016, it can be searched the calculation of growth rates after and before the airport operates in Muara Bungo Regency as follows.

GRDP Before operation PDRB after operation

$$
\begin{array}{rlrl}
2010-2013 & & 2013-2016 \\
P_{t}=P_{0} & \left(1+\frac{X}{100}\right)^{t} & P_{t} & =P_{0}\left(1+\frac{X}{100}\right)^{t} \\
6,198 & =4,033\left(1+\frac{X}{100}\right)^{3} & 14,351 & =6,198\left(1+\frac{X}{100}\right)^{3} \\
\frac{6,198}{4,033} & =\left(1+\frac{X}{100}\right)^{3} & \frac{14,351}{6,198} & =\left(1+\frac{X}{100}\right)^{3} \\
1,154^{\frac{1}{3}} & =\left(1+\frac{X}{100}\right) & 2,315^{\frac{1}{3}} & =\left(1+\frac{X}{100}\right) \\
X & =(1,154-1) \times 100 & X & =(1,322-1) \times 100 \\
& =15,4 \% & & =32,28 \%
\end{array}
$$

GRDP Growth Rate

$$
\begin{array}{rlrl} 
& 2013-2014 & & 2014-2016 \\
P_{t} & =P_{0}\left(1+\frac{X}{100}\right)^{t} & P_{t} & =P_{0}\left(1+\frac{X}{100}\right)^{t} \\
11,808 & =6,198\left(1+\frac{X}{100}\right)^{1} & 4,351 & =11,808\left(1+\frac{X}{100}\right)^{2} \\
\frac{11,808}{6,198} & =\left(1+\frac{X}{100}\right)^{1} & \frac{14,351}{11,808} & =\left(1+\frac{X}{100}\right)^{2} \\
1,905^{\frac{1}{1}} & =\left(1+\frac{X}{100}\right) & 1,215^{\frac{1}{2}} & =\left(1+\frac{X}{100}\right) \\
X & =(1,905-1) \times 100 & X & =(1,102-1) \times 100 \\
& =90,51 \% & & =10,24 \%
\end{array}
$$

From the results of the calculation of the growth rate in Muara Bungo District above, the average GRDP growth rate before operating was $14.16 \%$ and the average GRDP growth rate after operation was $32.28 \%$. While the GRDP growth rate in 20132014 was $90.51 \%$ and in 2014-2016 it was $10.24 \%$. As for the population growth rate using the same calculation, the population growth rate for 20132014 was $1.99 \%$ and for $2014-2016$ it was 2.2 so that the calculation results above can be assumed into the GRDP growth rate of Kulon Progo Regency. amounted to $82.91 \%$ of the value of $90.51 \%$ minus the value of the growth rate of Kulon Progo Regency $7.6 \%$ for the first year of operation of NYIA in 2019 - 2020 while for the second year 2021 onwards it was $7.6 \%$ from the growth rate of the Kulon Regency Progo Whereas the population growth rate for the first year 2019 - 2020 was $1.99 \%$ and for the second year 2021 thereafter was $2.2 \%$. The impact of the increase in these two factors influenced the loading of transformer I along with the GRDP growth and population. To more clearly the rate of load growth in transformer I can be seen in Table VI.

From the Table VI, it can be seen that after the operation of NYIA in 2019, the load increased significantly, which previously had not operated by NYIA in 2018 for transformer I of 21.46 MW after operating NYIA in 2019 to $31.50 \mathrm{MW}$ so that transformer I was only able serving the load until 2018 it was due to the influence of the operation of NYIA in 2019 which caused the loading to increase significantly to $31.50 \mathrm{MW}$ in the overload load category. Whereas, for transformer II with the influence of NYIA operation in 2019 which was originally in 2018 amounted to $18.66 \mathrm{MW}$ to 30.53 MW in 2019. Under the influence of NYIA the

\begin{tabular}{|c|c|c|c|c|}
\hline \multirow[b]{2}{*}{ Year } & \multicolumn{2}{|c|}{$\begin{array}{c}\text { Transformer I } \\
30 \text { MVA }\end{array}$} & \multicolumn{2}{|c|}{$\begin{array}{c}\text { Transformer II } \\
60 \text { MVA }\end{array}$} \\
\hline & $\begin{array}{c}\text { After } \\
\text { Opertae } \\
\text { NYIA } \\
(\mathrm{MW}) \\
\end{array}$ & $\begin{array}{l}\text { Percentage } \\
(\%)\end{array}$ & $\begin{array}{c}\text { After } \\
\text { Operate } \\
\text { NYIA } \\
(\mathrm{MW}) \\
\end{array}$ & $\begin{array}{c}\text { Percentage } \\
(\%)\end{array}$ \\
\hline 2018 & 21.46 & 71.55 & 18.66 & 31.10 \\
\hline 2019 & 31.50 & 105.00 & 30.53 & 50.89 \\
\hline 2020 & 35.34 & 117.81 & 35.59 & 59.31 \\
\hline 2021 & 39.41 & 131.37 & 40.82 & 68.04 \\
\hline 2022 & 43.73 & 145.76 & 46.26 & 77.10 \\
\hline 2023 & 48.31 & 161.03 & 51.90 & 86.50 \\
\hline 2024 & 53.18 & 177.28 & 57.75 & 96.26 \\
\hline 2025 & 58.38 & 194.59 & 63.84 & 106.40 \\
\hline 2026 & 63.92 & 213.05 & 70.17 & 116.95 \\
\hline 2027 & 69.83 & 232.77 & 76.75 & 127.92 \\
\hline
\end{tabular}
transformer II was only able to serve loading up to 2024 with load conditions weight of 57.75 MW with heavy loading conditions of $96.26 \%$, it is necessary to have intense supervision because it has exceeded the specified loading limit of $60-80 \%$ but if the loading is as specified, transformer II is only able to serve loads up to 8 by 2022 with a load of 46.26 MW with a load of $77.10 \%$. So as to anticipate the heavy load on transformer I after NYIA operation, the next step is to shift feeder transformer I to transformer II with data feeder load in May 2018 in Table VII. From the data R, S, and $\mathrm{T}$ then the sum and divided by three to get the average value. With this average value, the perfeeder loading can be obtained by dividing the average value by 30 as shown in Table VII.

TABLE VI

EFFECTS OF NYIA ON TRANSFORMER LOADS

From Table VII in 2018 exchange of feeder 5 to feeder 3 , feeder 4 to feeder 1 and feeder 2 shift to feeder 7 are carried out, considering that in 2019 transformer I was in overload load condition. With the change in feeder, the operating period for the loading of transformer I and transformer II can be up to 2021 with a load of 24.83 MW and 
transformer II of 55.40 MW. For more details the results of the shift feeder can be seen in Table VIII.

From the results of the shift in Table VIII above for transformer I in 2023 experienced overload load and only able to serve loading until 2022 with a heavy load of 29.15 MW while for transformer II after the shift transformer II was only able to serve loading up to the year 2021 with a heavy load category of $55.40 \mathrm{MW}$. If the shift is carried out, transformers I and transformers II will only be able to serve loads up to 2021 in the category of heavy load transformers while in 2022 to 2027 both transformers 9 will be overloaded. From the results of this shift, the next step in 2021 that must be taken is by Uprating transformer I to $60 \mathrm{MVA}$ and shifting feeder again considering the overload limit of the two transformers occurred in 2022. Data feeder in 2021 can be seen in Table IX from the results of calculations and growth trends in Muara Bungo Regency as an assumption of load growth in the Kulon Progo Regency of $82.91 \%$ in 2018 to 2019 while in 2019 to 2027 it was $7.6 \%$ transformer load.

From the data in Table IX, the next step is to shift feeder 3 to feeder 4 after uprating transformer I 30 MVA to 60 MVA so the results in Table $\mathrm{X}$ are obtained.

TABLE VII

FEEDER LOAD DATA FOR MAY 2018

\begin{tabular}{|c|c|c|c|c|c|c|c|c|c|}
\hline \multirow{2}{*}{ Data } & & \multirow{2}{*}{$\begin{array}{c}\begin{array}{c}\text { Load } \\
\text { (MW) }\end{array} \\
\text { R }\end{array}$} & \multirow{2}{*}{$\begin{array}{c}\text { Load } \\
\text { (MW) }\end{array}$} & \multirow{2}{*}{$\begin{array}{c}\begin{array}{c}\text { Load } \\
(\mathrm{MW})\end{array} \\
\mathrm{T}\end{array}$} & \multirow{2}{*}{ Average } & \multicolumn{2}{|c|}{ Transformer I } & \multicolumn{2}{|c|}{ Transformer II } \\
\hline & & & & & & Feeder & $\begin{array}{l}\text { Load } \\
\text { (MW) }\end{array}$ & Feeder & $\begin{array}{c}\text { Load } \\
\text { (MW) }\end{array}$ \\
\hline \multirow{3}{*}{ Transformer I } & WTS02 & 135.3 & 117.4 & 134 & 128.96 & WTS 2 & 4.29 & & \\
\hline & WTS04 & 198.6 & 106.2 & 135 & 146.9 & WTS 4 & 4.89 & & \\
\hline & WTS05 & 326.4 & 272.9 & 322 & 307.4 & WTS 5 & 10.24 & & \\
\hline \multirow{4}{*}{ Transformer II } & WTS01 & 14 & 12 & 24 & 16.66 & & & WTS 1 & 0.55 \\
\hline & WTS03 & 82 & 65 & 65 & 70.66 & & & WTS 3 & 2.35 \\
\hline & WTS06 & 171 & 151 & 111 & 144.33 & & & WTS 6 & 4.81 \\
\hline & WTS07 & 14 & 16 & 16 & 15.33 & & & WTS 7 & 0.51 \\
\hline Total & 7 & 941.3 & 740.5 & 809 & 830.24 & 3 & 19.42 & 4 & 8.22 \\
\hline
\end{tabular}

TABLE VIII

AFTER THE FEEDER SHIFT IN 2018

\begin{tabular}{|c|c|c|c|c|c|}
\hline \multirow[b]{2}{*}{ Year } & \multicolumn{3}{|c|}{$\begin{array}{c}\text { Transformer I } \\
30 \text { MVA }\end{array}$} & \multicolumn{2}{|c|}{$\begin{array}{c}\text { Transformer II } \\
60 \text { MVA }\end{array}$} \\
\hline & \multicolumn{2}{|c|}{$\begin{array}{c}\text { After } \\
\text { Operate } \\
\text { NYIA } \\
\text { (MW) }\end{array}$} & $\begin{array}{c}\text { Percentage } \\
(\%)\end{array}$ & $\begin{array}{c}\text { After } \\
\text { Operate } \\
\text { NYIA } \\
\text { (MW) }\end{array}$ & $\begin{array}{c}\text { Percentage } \\
(\%)\end{array}$ \\
\hline 2018 & \multicolumn{2}{|c|}{6.88} & 22.93 & 33.24 & 55.40 \\
\hline 2019 & \multicolumn{2}{|c|}{16.92} & 56.40 & 45.11 & 75.18 \\
\hline 2020 & \multicolumn{2}{|c|}{20.76} & 69.20 & 50.17 & 83.62 \\
\hline 2021 & \multicolumn{2}{|c|}{24.83} & 82.77 & 55.40 & 92.33 \\
\hline 2022 & \multicolumn{2}{|c|}{30.15} & 100.5 & 60.84 & 101.40 \\
\hline 2023 & \multicolumn{2}{|c|}{33.73} & 112.43 & 66.48 & 110.80 \\
\hline 2024 & \multicolumn{2}{|c|}{38.60} & 128.67 & 72.33 & 120.55 \\
\hline 2025 & \multicolumn{2}{|c|}{43.80} & 146.00 & 78.42 & 130.70 \\
\hline 2026 & \multicolumn{2}{|c|}{49.34} & 164.47 & 84.75 & 141.25 \\
\hline 2027 & \multicolumn{2}{|c|}{55.25} & 184.17 & 91.33 & 152.22 \\
\hline \multicolumn{6}{|c|}{$\begin{array}{c}\text { TABLE IX } \\
\text { FEEDER IN } 2021 \\
\end{array}$} \\
\hline \multicolumn{3}{|c|}{ Data } & \multicolumn{2}{|c|}{ Load (MW) } & Total (MW) \\
\hline \multirow{3}{*}{\multicolumn{2}{|c|}{ Transformer I }} & WT & \multicolumn{2}{|c|}{9.06} & \multirow{4}{*}{24.18} \\
\hline & & \multicolumn{2}{|c|}{ WTS04 } & $\begin{array}{l}.06 \\
.56\end{array}$ & \\
\hline & & WT & S05 & \multirow{2}{*}{$\begin{array}{l}56 \\
33\end{array}$} & \\
\hline \multirow{4}{*}{\multicolumn{2}{|c|}{ Transformer II }} & \multicolumn{2}{|c|}{ WTS01 } & & \\
\hline & & WT & S03 & 62 & \\
\hline & & WT & S06 & 55 & 54.94 \\
\hline & & WT & S07 & 45 & \\
\hline
\end{tabular}


TABLE X

RESULTS OF UPRATING TRANSFORMER I AND FEEDER SHIFT

\begin{tabular}{ccccc}
\hline \hline & \multicolumn{2}{c}{$\begin{array}{c}\text { Transformer I 30 } \\
\text { MVA }\end{array}$} & \multicolumn{2}{c}{$\begin{array}{c}\text { Transformer II 60 } \\
\text { MVA }\end{array}$} \\
\cline { 2 - 5 } Year & $\begin{array}{c}\text { After } \\
\text { Operate }\end{array}$ & $\begin{array}{c}\text { Percentage } \\
(\%)\end{array}$ & $\begin{array}{c}\text { After } \\
\text { Operate }\end{array}$ & $\begin{array}{c}\text { Percentage } \\
\text { NYIA }\end{array}$ \\
& NYIA & & \\
& $($ MW) & & 39.34 & 65.57 \\
2021 & 40.99 & 68.32 & 44.78 & 74.63 \\
2022 & 46.31 & 77.18 & 50.42 & 84.03 \\
2023 & 49.89 & 83.15 & 56.27 & 93.78 \\
2024 & 54.76 & 91.27 & 62.36 & 103.93 \\
2025 & 60.96 & 101.60 & 68.69 & 114.48 \\
2026 & 65.50 & 109.17 & 75.27 & 125.45 \\
2027 & 71.41 & 119.02 & \multicolumn{3}{c}{} \\
\hline \hline
\end{tabular}

From Table X transformers I and II are only able to serve loading up to 2024 in the heavy load category. For load of transformer I in 2024 of 54.76 MW and transformer II of 56.27 MW so that the $150 \mathrm{KV}$ Wates substation for the next 10 years requires the addition of transformer III in 2024 before overloading in 2025. From the addition of transformer III In 2024, the transformer feeder I and II shifted to transformer III feeder. With the addition of transformer III and shift in feeders in 2024 it is expected that the $150 \mathrm{KV}$ Wates substation will be able to serve loading up to the next 10 years with factors affecting the increase in transformer loading both by NYIA operating factors in 2019 as well as GRDP and other factors.

\section{Conclusion}

Based on the analysis of the calculation of the estimated transformer loading for the next 10 years at the $150 \mathrm{KV}$ Wates substation after assuming the GRDP growth of Muara Bungo district as a reference for load growth in Kulon Progo Regency the following conclusions are obtained:

1. For 2018 a shift in feeders from the transformer will be made. I to transformer II 10.

2. After shifting the feeder in 2018 the $150 \mathrm{KV}$ substation was only able to until 2021. Thus in 2021 the $150 \mathrm{KV}$ substation shifted the feeder again and uprating the 30 MVA transformer I to 60 MVA.

\section{Acknowledgements}

This work was supported by Universitas Muhammadiyah Yogyakarta.

\section{References}

[1] Allen Short, T. 2014. Electric Power System Distribution Handbook Second Edition. USA: CRC Press.

[2] IEEE Std. 1366-2012. 2012. IEEE Guide for Electric Power Distribution Reliability Indices. USA.

[3] R. P. W.S. Amarasinghe, W. G. K.P. Kumara, R. A. K.G. Rajapaksha, R. A. D.K. Rupasinghe, W. D. A.S. Wijayapala, "A transformer design optimisation tool for oil immersed distribution transformers", Moratuwa Engineering Research Conference (MERCon), pp. 100-105, 2015.

[4] Y. Li, M.-J. Tang, F.-J. Wu, G.-J. Zhang, S.-H. Wang Dan Suwarno, "Aging Assessment of Power Transformer Using Multi-parameters", International Journal on Electrical Engineering and Informatics, vol. 5, pp. 34-44, 2013.

[5] Suwarno R. A. Pasaribu, "Thermal Aging of Mineral Oil-Paper Composite Insulation for High Voltage Transformer", International Journal on Electrical Engineering and Informatics, vol. 8, no. 4, December 2016.

[6] A. A. Rahman, "Prakiraan Dan Analisis Kebutuhan Energi Listrik Provinsi Sumatra Barat Hingga Tahun 2024 Dengan Metode Analisis Regresi Linier Berganda, Padang," Institut Teknologi Padang, 2015.

[7] S. Suripto, R. A. Al Hasibi, and F. A. Nugroho, "Evaluasi Kemampuan Tranformator Gardu Induk Cilegon Lama $150 \mathrm{kV}$, , Thesis, Univeristas Muhammadiyah Yogyakarta, 2016.

[8] K. Murti P, "Evaluasi Kemampuan Transformator Daya Berdasarkan Perkembangan Penduduk Dan Beban Puncak Di Gardu Induk 150 KV Cikupa," Universitas Muhammadiyah Yogyakarta, 2017.

\section{Authors' information}

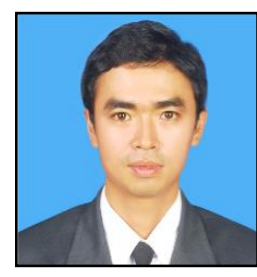

Yudhi Ardiyanto obtained his B.Eng. in Electrical Engineering from Universitas Muhammadiyah Yogyakarta, Indonesia in 2008. His Master study was done at 2015 at the Electrical Engineering, Universitas Gadjah Mada, Indonesia. He currently is a lecture in department of electrical engineering, Universitas Muhammadiyah

Yogyakarta.

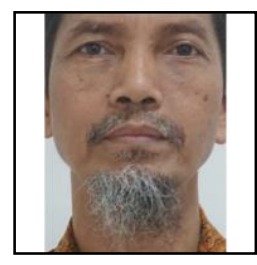

Slamet Suripto obtained his B.Eng. in Electrical Engineering from Universitas Gadjah Mada, Indonesia in 1987. His Master study was done at the Electrical Engineering, Universitas Gadjah Mada, Indonesia. He currently is a lecture in department of electrical engineering, Universitas Muhammadiyah Yogyakarta. 


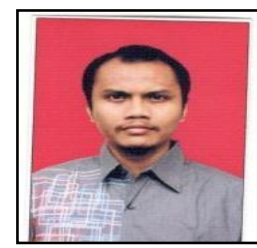

Faaris Mujaahid Hold a bachelor degree in 2010 from Electrical and Electronics Engineering Department, Saxion University of Applied Sciences, the Netherlands. He received a master degree in Sustainable Energy Technologies in 2016 from University of Southampton, UK. ing. Faaris Mujaahid, M.Sc. is currently a lecturer in the Department of Electrical Engineering, Faculty of Engineering, Universitas Muhammadiyah Yogyakarta, Indonesia. His main research interest is in LabVIEW and renewable energy (mainly in solar cell material and fabrication technologies).

Rohman Try Anshori obtained his B.Eng. in Electrical Engineering from Universitas Muhammadiyah Yogyakarta, Indonesia.

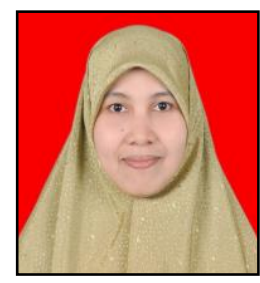

Yessi Jusman obtained her B.Eng. in Electrical and Electronic Engineering from Andalas University, Indonesia in 2007. She worked as a Research Assistant started in July 2008 until November 2009 in Universiti Sains Malaysia. Her Master study was done at 2012 at the School of Electrical and Electronic Engineering, USM Engineering Campus in Nibong Tebal, Penang, Malaysia. She was finished her Ph.D. degree at 2016 in University of Malaya with specializes in Image, Signal Processing, and algorithms. She currently is a lecture in department of electrical engineering, Universitas Muhammadiyah Yogyakarta.

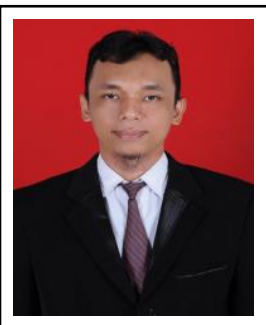

Fardhan Arkan Received B.Sc. degree from Department of Electrical Engineering Universitas Muhammadiyah Yogyakarta in 2000, M.Eng. degree from Department of Electrical Engineering, Universitas Andalas, Padang, Indonesia in 2014. Fardhan Arkan, M.Eng. is a Lecturer in Department of Electrical Engineering, Universitas Bangka Belitung, Indonesia. His research interests are in electronics, control system engineering, instrumentations, telecommunications, and its applications. 